\title{
Measuring the factors that contribute to the quality of services in the restaurants in Republic of Macedonia
}

\author{
Mislim Zendeli \\ State University of Tetovo, Tetovo, Macedonia \\ Blagica (Rizoska) Vanikj \\ University American College, Skopje, Macedonia
}

\begin{abstract}
The study examined the consumer behavior in the restaurant businesses in Macedonia. Aside from the data analyses for the differences of the perceptions of the factors that contribute towards the decision for visiting the restaurants among restaurant's employees and consumers, this paper contains the data about the factors that influence the customer satisfaction. Additionally, the research provides information about the main tools that customers use in order to inform themselves for different offers and services in different restaurants. The research has been based on the measurements for making analyses of the following factors: Quality, Accessibility, Food Decoration, Customer Care, Innovation, Taste of the food, Price, Hygiene, Ambience and Promotion. Based on the founding's, the data gives clearer picture for the focus, opportunities and challenges for developing the marketing strategy in the restaurant businesses in Macedonia. Additionally, the conclusions give directions for implementing advanced knowledge, techniques and methods for marketing analyses in the field of restaurant businesses. Finally, the study provides critical evaluation for the current situation of the marketing in restaurant businesses in Macedonia. The founding's give further recommendations for the development of the suitable marketing strategy in order to increase the customer satisfaction.
\end{abstract}

Key words: bringing decision, customer behavior, customer satisfaction, restaurant businesses

\section{Introduction}

The restaurant service is a complex category that integrates quality of the food, quality of the service, the atmosphere as well as the professional behavior. The restaurant businesses are organizationally, functionally and technically adapted to the food sector and integrate food preparation, food production and serving of the food, drinks and beverages. The restaurant businesses in Macedonia become very popular in the latest years since people start using the restaurant services more often as a result of the dynamic lifestyles and European working time.

It is expected that the today's customers in the restaurants will expect more sophisticated and specific food (Brady\& Cronin, 2001). The most of the people have access to many web pages and TV channels where they can educate themselves about the quality of the food as well as the different combinations of nutritive values that should satisfy their specific needs. Therefore they constantly expect different offers and services in order to have new experiences of the healthy and tasteful food (Стаменковска \& Јаќовски, 2013). Additionally, people travel abroad and visit different international restaurants that are offering food with different specific flavors and use products from different parts of the world. The restaurant businesses have a high market competition from one side and very well educated customers with very specific expectation for the food and restaurant services from the others (Wishna, 2000).

Today's restaurants should pay attention to many aspects of their work in order to satisfy the senses of the customers (Stack et al., 2006; Kotler, 1999; Andaleeb \& Conway, 2006). Having a satisfactory customer's experiences is crucial for attracting new customers and having a profitable restaurant business. In order to develop the restaurant business, the owners and managers must follow the global trends and implement the satisfactory standards of quality of the services (Kotler, 2002; Salai \& Bozidarevic, 2001). The main goal of this study is to investigate the factors that contribute to the customers decision to visit certain restaurant and use its services. Furthermore, the research provides very important data for the perceptions of the employees and customers regarding the factors that influence the customer satisfaction. The 
impact and uniqueness of the study rely on the fact that there are only few studies that offer the knowledge and information about the restaurant businesses in Republic of Macedonia. The research offers in-depth analyses of crucial factors for leading the restaurant businesses evaluated from the employees and customers. The results from the factor analyses confirmed that the Quality of the food, Hygiene, Taste of the food and Customer care are the main components that should be taken into consideration during the process of creating the successful developing strategy.

\section{Literature review}

The service is defined as the activity or benefit that one person/group/entity can offer to the others. The service is nonmaterial and it does not offer visible product. The difference in offering services compared to the offering products is that the service cannot be separated, it is produces and consumed in the same time, and it is variable and heterogeneous (Brown at al., 1993; Skallerud at al., 2009; Kotler at al., 2009). The specificity of the services rely on the fact that they are not presented as physical material products which means that the services cannot be valued on any way before the its consumption. Additionally, the production and consumption is conditioned from the personal presents of the customers of the services. The heterogeneity of the services means that there is a big number of the independent subjects in the process of production of the certain service. The variability of the services is presented into the fluctuation of the inquiry in different periods of the day, different days during the week or moths as well on the different seasons (Блеквел at al., 2009; Стојковска \& Јаќовски, 2013).

The restaurant service is a complicated activity since it includes the production of the food, the service of the food and drinks, the organizational activities as well as the trading activities. In order to be able to offer the restaurant services with the high quality, the restaurant should pay a special attention to the personnel, customers and technological support (Kotler, 2009; Laketa, 2000; Howard \& Sheth, 1969). The interest for the quality of the restaurant services is rapidly increasing in the latest 30 years. Therefore, today, there are many different definitions and different explanations that contain very subjective point of view. In order to define the quality of the restaurant services, we must take into consideration the fact that what is evaluated as high quality from customer can be considered as average quality by the other (Cobb, 1986; Dhar, 2000; Garvin, 1984). Therefore, the most of the studies that measure the quality of the restaurant services as well as the customer's satisfaction actually measure the customer's perceptions of the quality of the services. In order to be able to provide satisfactory customer experience, different sum of factors should be taken into consideration (Cousins at al., 2002; Ha \& Jang, 2010).

Many years, the researchers are trying to identify the suitable models for measuring the quality of the services in the restaurants Brown at al., 1993; Beatty\& Ferrell, 1998; Hirschman\& Holbrook, 1982). The focus in the most of the studies, is to compare the perception of expected quality with the perception of received quality from the customer's point of view. The restaurant's customers usually combine different visible and invisible factors in order to evaluate the dining experience. The main element is the offer of food and drinks combined with the atmosphere and professional behavior of the employees. The quality of the restaurant services usually includes the quality of the offer, the quality of the ambient and the customer care. It represents the difference between what have been expected and what have been experienced into the selected restaurant. If the customers have an internal feeling of satisfaction from the services offered in the restaurant, they will constantly visit the place and will recommend in to the other customers. To satisfy the customers is the best way to attract new customers. The customers visit the restaurants that are aware about their expectations and are able to satisfy their specific needs (Стојовска, 2014; Сениќ \& Сениќ, 2008; Seth at al., 2005).

The customer satisfaction represents the subjective feeling of the customer's experiences. Even though there are many factors that influence these experiences, the mostly investigated are the quality of the food, the quality of the service and the physical environment (Bitner, 1992). The quality of the food usually is experienced by using all of the senses: taste, smell, visual impression, temperature and sound. The physical environment is crucial for creating the first impression for the restaurant. The customers are expecting to the able to easily access to the restaurant, to have a parking place, than they become aware about the facility aesthetics, ambience, lighting etc. (Bitner, 1992; Babin \& Attaway, 2000; Kollat\& Willet, 1967). The hygiene is another important factor that contributes towards the decision for visiting certain restaurant and using its services. The safety and security of the food becomes the new base for the perception of the quality of the service in the restaurants (Маринковиќ, 2007). The customer care is another aspect that can increase or decrease the satisfaction of the customers. Taking care for the customers, following their specific needs and caring about their requirements in many cases is more important than the quality of the food and external environment (Namkung\& Jang, 2008; Popesku, 2005). 
Regarding the results from the previous research studies (Anderson \& Mittal, 2000; Bienstock at al., 2003; Dulen, 1999; Garvin, 2984), the high quality of the service is positively correlated with the high customer satisfaction. According to Zeithamal at al. (1996) the perception of the customers regarding the received services is the main factor that increases their satisfaction. The modern marketing literature differentiates two types of customer satisfaction: customer satisfaction based on transactions and overall satisfaction. The first type represents the perception related to the certain service related to the latest experience. The overall satisfaction is based on the overall experience and is not based on the single transaction (Gronroos, 1984; Kacen \& Lee, 2002). The process of measuring the customer satisfaction sometimes can be very challenging because of its changing character. Therefore, the most of the studies do not measure the customer satisfaction towards the certain service, nevertheless they measure the satisfaction from the attributes of its service.

The ability of the restaurants to recognize and satisfy the customer need is the main key for long term business development. The satisfied customers are loyal customers that send the positive message to the other potential clients. The factors that contribute towards the satisfaction of the customers may vary from one restaurant to another since the perception of quality is a subjective category and is contributed from the environment, culture and personality (Јовановска \& Јаковски, 2009; Kocap, 1998; Kotler, 1973). Many times the behavior of the employees have been recognized as the main factor for developing the relational dimension with the customer. According to many studies (Strack at al., 2006), the kindness, friendliness and willingness to help customers are the main skills and competences that restaurant's employees should develop in order to have a satisfied customers.

\section{Research methodology}

Taking into consideration the fact that the statistical data and marketing research for consumer behavior in the restaurant business in Macedonia is lacking, the main goal of the this research is the following: Analyzing the factors for bringing decision for visiting the restaurants and using restaurant services, and measuring the employees and customers satisfaction in the restaurants in Tetovo, Republic of Macedonia. The main questions that have been answered in this study are the following:

Which are the main factors for bringing decision for visiting restaurants and using its services?

Which are the key needs of the customers that are using the restaurant services?

Which factors influence the customer satisfaction in the restaurants in Macedonia?

The main subject of the research is to detect the key factors that influence the decision for visiting the restaurants and using the restaurant services, with additional analyses of the restaurants advantages and disadvantages. Additionally, the research is investigating the differences of the perceptions among the employees and customers for the following factors:

Quality

Accessibility

Decoration of the food

Customer care

Innovation

The taste of the food

Price

Hygiene

Ambience

Promotion

Finally, the research contains the statistical data for the perceptions of the employees and customers regarding the factors that contribute to the customer satisfaction. 


\section{Participants}

This research has been done on the data collected from 94 participants divided in 2 groups: Employees and Customers. The employees work in 10 different restaurants in Tetovo, Macedonia. From them $34(72,34 \%)$ are employees that serve customers while $13(27,66 \%)$ are managers of the restaurants. The most of them $(24-54,1 \%)$ are on the age of $20-30$ years, $12(25,5 \%)$ are on the age of 30-40 years, 8 are on the age of $40-50$ years and 3 of them are on the age above 50 years. Only 6 participants from the group of employees are females while 41 are males. The majority $(51,1 \%)$ have high education while $34 \%$ have finished high school. Regarding the working experience, the most of them have 5-10 years working experience (34\%), 29,8 are with working experience in the range of $1-5$ years, while $25,5 \%$ are with working experience from $10-15$ years. The most of the participants are Albanians $(89,36 \%)$ while 5 of them $(10,64 \%)$ are Macedonians.

The majority of the customers that participated in this research are on the age of $30-40$ years (36,2\%), $34 \%$ are on the age of $20-30$ years and $29,8 \%$ are on the age above 40 years. There are 32 male customers and 15 female customers. Only $12,8 \%$ have finished the high school while the $87,2 \%$ have finished faculty or master degree. The most of the customers are Albanians $(89,36 \%)$ while 5 of them $(10,64 \%)$ are Macedonians.

\section{Questionnaires and procedure}

The data for this research has been collected by using the combination of questions that have been separately created for the employees and customers. The author created the new questionnaires on Macedonian and Albanian language. The questionnaires for the employees and clients contain 10 questions. By using the scale of 1-5 the participants are evaluating the factors that are crucial for bringing decision for going in the certain restaurant as well as their perceptions for the factors that contribute to the customer satisfaction. The data has been collected in the period of JulySeptember 2017. The questionnaires have been distributed in the hard copies by the researchers. The participants filled in the questionnaires individually. The total number of the distributed questionnaires was 103.

\section{Results and discussion}

According to the analyses of the data collected from the employees and customers in the restaurants in Tetovo, Macedonia, the main factors for bringing decision for visiting certain restaurant are the Hygiene, Quality of the food, Customer care and the Taste of the food. From the other side the Promotion and Accessibility have the lowest scores for both of the groups. The scores of the employees for all of the factors for bringing decision for visiting restaurants are higher than the scores of the customers. However, all of the factors have been evaluated with higher scores than the expected average in both of the groups. Based on the results received from the analyses on the mean differences (t-test), the differences in the perception of the factors that contribute towards the decision for visiting restaurants and using its services among employees and customers, are statistically important for the factors Hygiene and Accessibility. Therefore, it can be concluded that employees have a perception that the Hygiene and Accessibility are more important factors for visiting the restaurants and using its services in comparison to the perception of the customers .

Based on the analysis of the answers of the question: Which are the advantages and disadvantages of the restaurants that you are visiting/in which you are working compared to the other restaurants?, the main advantages are Quality of the food and Customer care in both groups the employees and the customers. From the other side, the main disadvantages for the employees are Customer care, Accessibility and Promotion. The customers consider that Innovativeness, Taste of the food, and Hygiene are the main disadvantages of the restaurants that they are visiting.

The additional analyses of perception of the factors that contribute towards customer satisfaction confirmed that both employees and customers consider that the Tasteful food, Professional service and Customer care are crucial factors for customer's satisfaction. However, the employees evaluated all of the factors higher than the customers. The received means of the scores for both groups are higher than the expected mean. 


\begin{tabular}{|c|c|c|c|c|c|c|c|c|c|c|c|}
\hline & $\begin{array}{l}\text { Table 1. Des } \\
\text { and using th }\end{array}$ & riptiv & $\begin{array}{c}\text { cs and } \\
\text { rvices }\end{array}$ & or the $f$ & tors the & ontrib & on the & cision & risit & he re & rants \\
\hline \multirow{3}{*}{ Quality } & Group & $\mathbf{N}$ & M & $\sum M$ & $\delta$ & $\delta \mathrm{D}$ & D & $\mathrm{F}$ & df & $\mathrm{t}$ & $\mathrm{p}$ \\
\hline & Employees & 47 & 4,60 & \multirow[b]{2}{*}{4,64} & 0,83 & 0,12 & \multirow[b]{2}{*}{$-0,09$} & \multirow[b]{2}{*}{0,87} & \multirow[b]{2}{*}{92} & $-0,48$ & \multirow[b]{2}{*}{0,35} \\
\hline & Customers & 47 & 4,68 & & 0,89 & 0,13 & & & & $-0,48$ & \\
\hline \multirow[t]{2}{*}{ Accessibility } & Employees & 47 & 4,02 & \multirow[b]{2}{*}{3,85} & 1,03 & 0,15 & \multirow[b]{2}{*}{0,34} & \multirow[b]{2}{*}{4,33} & \multirow[b]{2}{*}{92} & 1,31 & 0,04 \\
\hline & Customers & 47 & 3,68 & & 1,45 & 0,21 & & & & 1,31 & * \\
\hline \multirow[t]{2}{*}{ Food decoration } & Employees & 47 & 4,09 & \multirow[b]{2}{*}{3,86} & 1,04 & 0,15 & \multirow[b]{2}{*}{0,45} & \multirow[b]{2}{*}{2,74} & \multirow[b]{2}{*}{92} & 1,86 & \multirow[b]{2}{*}{0,10} \\
\hline & Customers & 47 & 3,64 & & 1,28 & 0,19 & & & & 1,86 & \\
\hline \multirow[t]{2}{*}{ Customer care } & Employees & 47 & 4,64 & \multirow[b]{2}{*}{4,59} & 0,74 & 0,11 & \multirow[b]{2}{*}{0,11} & \multirow[b]{2}{*}{1,34} & \multirow[b]{2}{*}{92} & 0,57 & \multirow[b]{2}{*}{0,25} \\
\hline & Customers & 47 & 4,53 & & 1,04 & 0,15 & & & & 0,57 & \\
\hline \multirow[t]{2}{*}{ Innovativeness } & Employees & 47 & 4,17 & \multirow[b]{2}{*}{3,96} & 0,96 & 0,14 & \multirow[b]{2}{*}{0,43} & \multirow[b]{2}{*}{3,05} & \multirow[b]{2}{*}{92} & 1,86 & \multirow[b]{2}{*}{0,08} \\
\hline & Customers & 47 & 3,74 & & 1,24 & 0,18 & & & & 1,86 & \\
\hline \multirow[t]{2}{*}{ Taste of the food } & Employees & 47 & 4,62 & \multirow[b]{2}{*}{4,59} & 0,77 & 0,11 & \multirow[b]{2}{*}{0,06} & & & 0,36 & \\
\hline & Customers & 47 & 4,55 & & 0,95 & 0,14 & & 0,13 & 92 & 0,36 & 0,72 \\
\hline Price & Employees & 47 & 4,21 & & 0,95 & 0,14 & & & & 1,02 & \\
\hline & Customers & 47 & 3,98 & 4,10 & 1,26 & 0,18 & 0,23 & 2,41 & 92 & 1,02 & 0,12 \\
\hline Hygiene & Employees & 47 & 4,77 & & 0,60 & 0,09 & & & & 0,99 & 0,05 \\
\hline & Customers & 47 & 4,60 & 4,68 & 1,01 & 0,15 & 0,17 & 3,89 & 92 & 0,99 & * \\
\hline Ambience & Employees & 47 & 4,40 & & 0,92 & 0,13 & & & & 1,03 & \\
\hline & Customers & 47 & 4,19 & 4,30 & 1,08 & 0,16 & 0,21 & 0,70 & 92 & 1,03 & 0,40 \\
\hline Promotion & Employees & 47 & 4,06 & 361 & 1,09 & 0,16 & 091 & 132 & 92 & 3,59 & 025 \\
\hline & Customers & 47 & 3,15 & 3,01 & 1,37 & 0,20 & 0,91 & 1,32 & 92 & 3,59 & $0, \angle 0$ \\
\hline
\end{tabular}

According to the results received from the analyses of the scores of the employees, the main factors for customer satisfaction are Professional service, Tasteful food and Customer care while the lowest scores are given to the factors: Personal parking, Easy access to the restaurant and the Promotional packages. From the other side, according to the perceptions of the customers, the most important factors for customer satisfaction are Tasteful food, Optimal hygiene and Customer care. The lowest scores evaluated by the customers are given to the Personal parking, Different methods of food promotion and Promotional packages.

The analyses of the differences of the means among employees and customers are presenting that there are statistically important results for the factors Tasteful food, Professional service, Quality standards, Eco standards and Price. Hence, it can be concluded that employees consider the Tasteful food, Professional service, Quality standards, Eco standards, and Price as more important factors that influence the customer satisfaction than the customers. 
The results from the analyses of the scores for the question: Do you have marketing strategy?, present that $80,9 \%$ from the employees have answered that they have their own marketing strategy while $17 \%$ have answered that they do not have the marketing strategy in the restaurant in which they are working. Concerning the most used tools for informing the customers for the offers and services in the restaurant, 23 employees $(48,9 \%)$ have answered that they use the recommendations (friends) in order to promote their offers and services. Additionally $36,2 \%$ use the internet tools while 8,5 use the TV as the main tool for promotion. Only $4.2 \%$ use printed materials as the tool for informing the customers about their offers and services. From the other side, the most used tool that customers use in order to inform themselves for the offers and services in the restaurants is the recommendations (friends) $51,1 \%, 27,7 \%$ from the customers use internet while $6,4 \%$ inform themselves from the TV.

\begin{tabular}{|c|c|c|c|c|c|c|c|c|c|c|}
\hline & \multicolumn{10}{|c|}{$\begin{array}{l}\text { Table 2: Descriptive statistics and t-test for the advantages and disadvantages of the restaurants based } \\
\text { on the perceptions of the employees and customers }\end{array}$} \\
\hline & \multirow{3}{*}{ Group } & \multirow{3}{*}{ N } & \multicolumn{4}{|c|}{ Advantages } & \multicolumn{4}{|c|}{ Disadvantages } \\
\hline & & & \multicolumn{2}{|c|}{ Frequency } & \multicolumn{2}{|c|}{ Percentage } & \multicolumn{2}{|c|}{ Frequency } & \multicolumn{2}{|c|}{ Percentage } \\
\hline & & & Yes & No & Yes & No & Yes & No & Yes & No \\
\hline & Employees & 47 & 40 & 7 & 85,1 & 14,9 & 9 & 38 & 19,1 & 80,9 \\
\hline \multirow[t]{3}{*}{ Quality } & Customers & 47 & 42 & 5 & 89,4 & 10,6 & 17 & 30 & 36,2 & 63,8 \\
\hline & Total & 94 & 41 & 6 & 87,25 & 12,75 & 13 & 34 & 27,65 & 72,35 \\
\hline & Employees & 47 & 15 & 32 & 31,9 & 68,1 & 15 & 32 & 31,9 & 68,1 \\
\hline \multirow[t]{3}{*}{ Accessibility } & Customers & 47 & 19 & 28 & 40,4 & 59,6 & 13 & 34 & 27,7 & 72,3 \\
\hline & Total & 94 & 17 & 30 & 36,15 & 63,85 & 14 & 33 & 29,8 & 70,2 \\
\hline & Employees & 47 & 20 & 27 & 42,6 & 57,4 & 6 & 41 & 12,8 & 87,2 \\
\hline \multirow[t]{3}{*}{ Food decoration } & Customers & 47 & 14 & 33 & 29,8 & 70,2 & 14 & 33 & 29,8 & 70,2 \\
\hline & Total & 94 & 17 & 30 & 36,2 & 63,8 & 10 & 37 & 21,3 & 78,7 \\
\hline & Employees & 47 & 11 & 36 & 76,6 & 23,4 & 6 & 41 & 87,2 & 12,8 \\
\hline \multirow[t]{3}{*}{ Customer care } & Customers & 47 & 36 & 11 & 76,6 & 23,4 & 14 & 33 & 29,8 & 70,2 \\
\hline & Total & 94 & 23,5 & 23,5 & 76,6 & 23,4 & 10 & 37 & 58,5 & 41,5 \\
\hline & Employees & 47 & 19 & 28 & 40,4 & 59,6 & 8 & 39 & 17 & 83 \\
\hline \multirow[t]{3}{*}{ Innovativeness } & Customers & 47 & 17 & 30 & 36,2 & 63,8 & 19 & 28 & 40,4 & 59,6 \\
\hline & Total & 94 & 18 & 29 & 38,3 & 61,7 & 13,5 & 33,5 & 28,7 & 71,3 \\
\hline & Employees & 47 & 33 & 14 & 70,2 & 29,8 & 5 & 42 & 10,6 & 89,4 \\
\hline \multirow[t]{3}{*}{ Taste of the food } & Customers & 47 & 33 & 14 & 70,2 & 29,8 & 19 & 28 & 40,4 & 59,6 \\
\hline & Total & 94 & 33 & 14 & 70,2 & 29,8 & 12 & 35 & 25,5 & 74,5 \\
\hline & Employees & 47 & 20 & 27 & 42,6 & 57,4 & 12 & 35 & 25,5 & 74,5 \\
\hline \multirow[t]{3}{*}{ Price } & Customers & 47 & 17 & 30 & 36,2 & 63,8 & 14 & 33 & 29,8 & 70,2 \\
\hline & Total & 94 & 18,5 & 28,5 & 39,4 & 60,6 & 13 & 34 & 27,65 & 72,35 \\
\hline & Employees & 47 & 29 & 18 & 61,7 & 38,3 & 9 & 38 & 19,1 & 80,9 \\
\hline \multirow[t]{2}{*}{ Hygiene } & Customers & 47 & 10 & 37 & 78,7 & 21,3 & 15 & 32 & 31,9 & 68,1 \\
\hline & Total & 94 & 19,5 & 27,5 & 70,2 & 29,8 & 12 & 35 & 25,5 & 74,5 \\
\hline \multirow{2}{*}{ Ambience } & Employees & 47 & 30 & 17 & 63,8 & 36,2 & 8 & 39 & 17 & 83 \\
\hline & Customers & 47 & 25 & 22 & 53,2 & 46,8 & 10 & 37 & 21,3 & 78,7 \\
\hline
\end{tabular}




\begin{tabular}{|c|c|c|c|c|c|c|c|c|c|c|}
\hline & Total & 94 & 27,5 & 19,5 & 58,5 & 41,5 & 9 & 38 & 19,15 & 80,85 \\
\hline & Employees & 47 & 14 & 33 & 29,8 & 70,2 & 20 & 26 & 43,5 & 56,5 \\
\hline \multirow[t]{2}{*}{ Promotion } & Customers & 47 & 37 & 10 & 21,3 & 78,7 & 16 & 31 & 34 & 66 \\
\hline & Total & 94 & 25,5 & 21,5 & 25,55 & 74,45 & 18 & 28,5 & 38,75 & 61,25 \\
\hline
\end{tabular}

\begin{tabular}{|c|c|c|c|c|c|c|c|c|c|c|}
\hline & Group & $\mathrm{N}$ & M & $\delta$ & $\delta D$ & D & $\mathrm{F}$ & df & $t$ & $\mathrm{p}$ \\
\hline \multirow{3}{*}{ Tasteful food } & Employees & 47 & 4,70 & 0,69 & 0,10 & \multirow{3}{*}{0,27} & \multirow{3}{*}{6,04} & \multirow{3}{*}{92} & \multirow{3}{*}{1,61} & \multirow{3}{*}{$0,01^{* *}$} \\
\hline & Customers & 47 & 4,43 & 0,95 & 0,14 & & & & & \\
\hline & Total & 94 & 4,57 & & & & & & & \\
\hline \multirow{3}{*}{ Professional service } & Employees & 47 & 4,74 & 0,61 & 0,09 & \multirow{3}{*}{0,57} & \multirow{3}{*}{22,21} & \multirow{3}{*}{92} & \multirow{3}{*}{3,29} & \multirow{3}{*}{$0^{* *}$} \\
\hline & Customers & 47 & 4,17 & 1,03 & 0,15 & & & & & \\
\hline & Total & 94 & 4,46 & & & & & & & \\
\hline \multirow{2}{*}{$\begin{array}{l}\text { Rich offer of food and } \\
\text { drinks }\end{array}$} & Employees & 47 & 4,34 & 0,84 & 0,12 & \multirow{2}{*}{0,34} & \multirow{2}{*}{0,33} & \multirow{2}{*}{92} & \multirow{2}{*}{1,83} & \multirow{2}{*}{0,57} \\
\hline & $\begin{array}{l}\text { Customers } \\
\text { Total }\end{array}$ & $\begin{array}{l}47 \\
94\end{array}$ & $\begin{array}{l}4,00 \\
4,17\end{array}$ & 0,96 & 0,14 & & & & & \\
\hline \multirow[b]{2}{*}{ Personal parking } & Employees & 47 & 3,83 & 1,37 & 0,20 & \multirow{2}{*}{0,43} & \multirow{2}{*}{0,18} & \multirow{2}{*}{92} & \multirow{2}{*}{1,50} & \multirow{2}{*}{0,67} \\
\hline & $\begin{array}{l}\text { Customers } \\
\text { Total }\end{array}$ & $\begin{array}{l}47 \\
94\end{array}$ & $\begin{array}{l}3,40 \\
3,62\end{array}$ & 1,38 & 0,20 & & & & & \\
\hline \multirow{4}{*}{$\begin{array}{l}\text { Easy access to the } \\
\text { restaurant }\end{array}$} & Employees & 47 & 4,04 & 1,08 & 0,16 & \multirow{3}{*}{0,34} & 236 & 92 & 140 & 13 \\
\hline & Customers & 47 & 3,70 & 1,27 & 0,18 & & 2,00 & 92 & 1,40 & 0,10 \\
\hline & Total & 94 & 3,87 & & & & & & & \\
\hline & Employees & 47 & 4,47 & 0,80 & 0,12 & 0,07 & 0,81 & 92 & 0,35 & 0,37 \\
\hline Optimal hygiene & $\begin{array}{l}\text { Customers } \\
\text { Total }\end{array}$ & $\begin{array}{l}47 \\
94\end{array}$ & $\begin{array}{l}4,40 \\
4,44\end{array}$ & 0,95 & 0,14 & & & & & \\
\hline Sophisticated internal & Employees & 47 & 4,53 & 0,80 & 0,12 & 0.47 & 172 & 92 & 252 & 019 \\
\hline design and lightening & $\begin{array}{l}\text { Customers } \\
\text { Total }\end{array}$ & $\begin{array}{l}47 \\
94\end{array}$ & $\begin{array}{l}4,06 \\
4,30\end{array}$ & 0,99 & 0,14 & $0,7 t$ & $1, I L$ & 92 & $2,0<$ & 0,10 \\
\hline Food serving & Employees & 47 & 4,38 & 0,97 & 0,14 & 0.49 & 1.26 & 92 & 230 & 0.26 \\
\hline innovativeness & $\begin{array}{l}\text { Customers } \\
\text { Total }\end{array}$ & $\begin{array}{l}47 \\
94\end{array}$ & $\begin{array}{l}3,89 \\
4,14\end{array}$ & 1,09 & 0,16 & & & & & \\
\hline & Employees & 47 & 4,40 & 0,83 & 0,12 & 038 & 331 & 92 & 192 & \\
\hline Suitable equipment & Customers & 47 & 4,02 & 1,09 & 0,16 & , & 3,31 & 92 & 1,92 & 0,01 \\
\hline & & 94 & 4,21 & & & & & & & \\
\hline Customer care/Client & Employees & 47 & 4,62 & 0,87 & 0,13 & 0,26 & 2,29 & 92 & 1,38 & 0,13 \\
\hline service & $\begin{array}{l}\text { Customers } \\
\text { Total }\end{array}$ & $\begin{array}{l}47 \\
94\end{array}$ & $\begin{array}{l}4,36 \\
4,49\end{array}$ & 0,92 & 0,13 & & & & & \\
\hline & Employees & 47 & 4,43 & 0,83 & 0,12 & 039 & 430 & 92 & 190 & $004^{*}$ \\
\hline Quality standards & Customers & 47 & 4,04 & 1,10 & 0,16 & 0,00 & 4, & JL & 1, & 0,04 \\
\hline & Total & 94 & 4,23 & & & & & & & \\
\hline & Employees & 47 & 4,19 & 0,97 & 0,14 & 0,62 & 2,40 & 92 & 2,72 & 0,12 \\
\hline New innovative offers & $\begin{array}{l}\text { Customers } \\
\text { Total }\end{array}$ & $\begin{array}{l}47 \\
94\end{array}$ & $\begin{array}{l}3,57 \\
3,88\end{array}$ & 1,21 & 0,18 & & & & & \\
\hline Modern models of & Employees & 47 & 4,19 & 0,99 & 0,14 & 0.47 & 007 & 92 & 221 & 0.78 \\
\hline equipment & Customers & 47 & 3,72 & 1,06 & 0,15 & & & & & \\
\hline & & 94 & 4,03 & & & & & & & \\
\hline $\begin{array}{l}\text { Modern techniques of } \\
\text { food preparation }\end{array}$ & Employees & 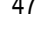 & 4,23 & 0,81 & 0,13 & 0,59 & 1,51 & 92 & 3,03 & 0,22 \\
\hline 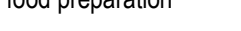 & Customers & 47 & 3,64 & 1,03 & 0,15 & & & & & \\
\hline
\end{tabular}




\begin{tabular}{||lllllllllll||} 
& Total & 94 & 3,94 & & & & & & & \\
Different tastes of the & Employees & 47 & 4,38 & 0,92 & 0,13 & 0,55 & 0,05 & 92 & 2,84 & 0,83 \\
food & Customers & 47 & 3,83 & 0,96 & 0,14 & & & & & \\
& Total & 94 & 4,11 & & & & & & & \\
Eco standards of food & Employees & 47 & 4,55 & 0,77 & 0,11 & 0,51 & 10,99 & 92 & 2,70 & $0^{* *}$ \\
preparation & Customers & 47 & 4,04 & 1,04 & 0,15 & & & & & \\
& Total & 94 & 4,30 & & & & & & & \\
Different offers for & Employees & 47 & 4,36 & 0,79 & 0,12 & 0.36 & 1,21 & 92 & 1,97 & 0,27 \\
different client's needs & Customers & 47 & 4,00 & 0,98 & 0,14 & & & & & \\
& Total & 94 & 4,18 & & & & & & & \\
Price correspond to & Employees & 47 & 4,47 & 0,75 & 0,11 & 0,6 & 13,61 & 92 & 2,81 & $0^{* *}$ \\
quality of the food & Customers & 47 & 3,87 & 1,24 & 0,18 & & & & & \\
& Total & 94 & 4,17 & & & & & & & \\
Different methods of food & Employees & 47 & 4,23 & 0,84 & 0,12 & 1 & 0,21 & 92 & 5,45 & 0,64 \\
promotion & Customers & 47 & 3,23 & 0,94 & 0,14 & & & & & \\
Interesting promotional & Total & 94 & 3,73 & & & & & & \\
packages & Employees & 47 & 4,00 & & & & & & \\
& Customers & 47 & 3,19 & 1,10 & 0,16 & 0,81 & 0,07 & 92 & 3,56 & 0,78 \\
\hline
\end{tabular}

Taking into consideration that the most of the participants still use the recommendations (friends) as the main tool for informing themselves and there are still restaurants that do not have their own marketing strategy, it can be concluded that the awareness for using different marketing tools is on the very low level. Only $36,2 \%$ from the employees are using the internet as a tool for informing their customers regarding their offers and services. It can be concluded that in the future, there should be a further research regarding the functionality of the web portals as well as the presence of the Macedonian restaurants on the social network. Additionally, the focus of the managerial teams into the restaurants should be on strengthening the capacities of the human resources through training and education for using social media as the tool for marketing and sales.

Furthermore, it is very important to invest into the infrastructure of the restaurants. According to the results, the most of them may increase their potential for development if they invest in personal parking and if it is easier to access to them (Bitner, 1992; Babin \& Attaway, 2000; Kollat\& Willet, 1967). Additional aspects that should be developed in the future are the Eco standards as well as the standards for Professional behavior (Kotler, 2002; Salai \& Bozidarevic, 2001). The restaurants should offer the tasteful food with high quality adapted to the needs of the clients. The customer care has been detected as one of the most important factors for bringing decision for visiting the restaurants as well as for the customer satisfaction. The restaurant personnel should be proactive and able to constantly recognize the needs of the customers in order to be able to offer the most suitable offer and service (Namkung\& Jang, 2008; Popesku, 2005).

The management of the restaurant should constantly investigate the level of satisfaction of the customers. The main focus should be the customers that are loyal and are coming often into the restaurant. The obtained results can be solid information for bringing better decisions and creating marketing strategy that is adapted to the needs of the customers. In order to create the marketing strategy adapted to the needs of the customers it is very important to take into consideration that the same message will be accepted differently from different groups of customers. The customers will be selective and their perception will be in line with their expectations based on the previous experiences (Brown at al., 1993; Beatty\& Ferrell, 1998; Hirschman\& Holbrook, 1982). Therefore, they will refuse and forget all of the messages that do not correspond to their personal beliefs. Hence, it is very important to create the marketing strategy that will offer an opportunity to educate the customers during the process of consumption that will create new perceptions for the needs of certain services. During this process, the restaurant's employees should be skilled for customer relation management in order to be able to interactively communicate with the clients and continuously educate them. The educated customer is aware about the new trends of the food consumption and its effects on the eating habits and environment. The key influences in this process have the media especially the internet (Стојовска, 2014; Сениќ \& Сениќ, 2008; Seth at al., 2005).

The questionnaires used in this research study are measuring 10 factors; however it does not cover all of the factors that are crucial for the success of the restaurant business. The future research should include new constellations in order to 
provide more detailed results for different aspects of the customer satisfaction. Furthermore, more restaurants from different parts of Macedonia should be taken into consideration on order to be able to provide results for the whole country. Finally, the sample of participants should include more participants with different demographic characteristics (gender, age, ethnicity, education, experience etc.), in order to be able to create more different groups and make further in-depth analyses.

\section{Conclusion}

Based on the founding's, the following can be concluded:

The awareness for the marketing strategy adapted to the needs of the clients as well as the investment in developing and using different marketing tools is still on the low level and requires additional research in the future.

The managerial teams in the restaurant businesses in Macedonia should strengthen the capacities of human resources through increasing the knowledge for consumer behavior as well the skills for professional service and customer care.

The employees in the restaurants in Macedonia should be encouraged to use modern marketing tools (online marketing and social media) for informing the customers.

The employees in the restaurants in Macedonia should be trained and educated for the newest trends in the food industry, they should develop their capacities for implementing creative technologies of food preparation and to use the innovative approaches or serving the food.

\section{Literature}

[1] Andaleeb, S.S. \& Conway, C. (2006). Customer satisfaction in the restaurant industry: an examination of the transaction-specific model, Journal of Services Marketing, 20 (1), 3-11.

[2] Anderson, E. \& Mittal, V. (2000). Strengthening the satisfaction-profit chain, Journal of Service Research, 3 (2), 107-20.

[3] Babin, B.J. \& Attaway, J.S. (2000). Atmospheric affect as a tool for creating value and gaining share of customer. Journal of Business Research, 49, 91-99.

[4] Beatty, S.E. \& Ferrell, M.E. (1998). Impulse buying: modeling its precursors. Journal of Retailing, 74, 169-191.

[5] Bienstock, C. C., Demoranville, C. W., \& Smith, R. K. (2003). Organizational citizenship behavior and service quality. Journal of Services Marketing, 17(4), 357-78.

[6] Bitner, M. J. (1992). Servicescapes: the impact of physical surroundings on customers and employees. Journal of Marketing, 56, 57-71.

[7] Блеквел, Д, Р., Миниард, В. П. \& Енџел, Ф, Д. (2009). Однесување на потрошувачите. (македонски превод)

[8] Blattberg, R.C., Briesch, R. \& Fox, E.J. (1995). How promotions work. Marketing Science, 14 (3), 122-132.

[9] Brady, M. K., \& Cronin, J. J. (2001). Some new thoughts on conceptualizing perceived service quality: a hierarchical approach. Journal of Marketing, 65(3), 34-49

[10] Brown, T. J., Churchill, G. A., \& Peter, J. P. (1993). Improving the measurement of service quality. Journal of Retailing, 69(1), 127-139.

[11] Campbell-Smith, G. (1967). The Marketing of the Meal Experience, London: University of Surrey Press.

[12] Cobb, C.J. \& Hoyer, W.D. (1986). Planned versus impulse purchase behavior. Journal of Retailing 4, 384-409

[13] Cousins, J., Foskett, D., \& Gillespie, C. (2002). Food and Beverage Management, Harlow: 2nd ed., PrenticeHall.

[14] Dhar, R. \& Wertenbroch, K. (2000). Consumer choice between hedonic and utilitarian goods. Journal of Marketing Research 37, 60-71.

[15] Dulen, J. (1999). Quality control. Restaurant \& Institutions, 109(5), 38-52.

[16] Garvin, D. (1984). Product quality: an important strategic weapon. Business Horizons, 27(3), 40-43.

[17] Grönroos, C. (1984). A service quality model and its marketing implications. European Journal of Marketing, 18(4), 36-44. 
[18] Ha, J., \& Jang, S. (2010). Perceived values, satisfaction and behavioral intentions: The role of familiarity in Korean restaurants. International Journal of Hospitality Management, 29(1), 2-13.

[19] Hirschman, E.C. \& Holbrook, M.B. (1982). Hedonic consumption: emerging concepts, methods, and propositions. Journal of Marketing, 46, 92-101.

[20] Howard, J.A.\& Sheth, J.N. (1969). The Theory of Buyer Behavior. New York: Wiley

[21] Јовановска, Р, С. \& Јаќовски, Б. (2009). Маркетине. Скопје

[22] Kacen, J.J. \& Lee, J.A. (2002). The influence of culture on consumer impulsive buying behavior. Journal of Consumer Psychology, 12 (2), 163-176.

[23] Kollat, D.T. \& Willett, R.P. (1967). Customer impulse purchasing behavior. Journal of Marketing Research 4, 2131.

[24] Косар, Љ. (1998). Хотелијерство. Београд: Савезни центар за унапређење хотелијерстваугоститељства.

[25] Котлер, Ф., Армстронг, Г., Саундерс, Џ. \& Вонг, В. (2009). Принцип на маркетинг . Трето Европско издание. (македонски превод)

[26] Котлер,Ф. (1999). Управљање маркетинга. Загреб: Информатор.

[27] Kotler, P. (2002). Marketing Menagement. New Jersey: Prentice Hall.

[28] Котлер, F. (2009). Маркетинг од А до Ш. Скопје: Матица.

[29] Kotler, P. (1973). Atmospherics as a marketing tool. Journal of Retailing, 49, 48-64.

[30] Laketa, M. (2000). Istraživanje marktinga u funkciji razvoja kompanije. Beograd: Narodna Knjiga.

[31] Laketa, M. (2009). Marketing u funkciji razvoja kompanija. Beograd: Narodna knjiga.

[32] Маринковић, В. (2007). Креирање базе лојалних потрошача. Економски хоризонти, 9(1-2), 109-127.

[33] Namkung, Y., \& Jang, S. (2008). Are highly satisfied restaurant customers really different? A quality perception perspective. International Journal of Contemporary Hospitality Management, 20(2), 142-155.

[34] Popesku, K. (2005). Marketing. Beograd: Narodna Knjiga.

[35] Rajcic,N, B. (2008). Marketing. Novi Sad

[36] Salai, S. \& Bozidarevic, D. (2001). Marketing istraživanje. Beograd: Savremena administracija.

[37] Сенић, Р., \& Сенић, В. (2008). Манаимент и маркетинг услуга. Крагујевац: Призма.

[38] Seth, N., Deshmunkh, S. G., \& Vrat, P. (2005). Service quality models: A review. International Journal of Quality and Reliability Management, 22(9), 913-949.

[39] Skallerud, K., Korneliussen, T. \& Olsen, S.O. (2009). An examination of consumers' cross- shopping behavior. Journal of Retailing and Consumer Services, 16 (3), 181-189.

[40] Strack, F., Werth, L. \& Deutsch, R. (2006). Reflective and impulsive determinants of consumer behavior. Journal of Consumer Psychology, 16(3), 205-216.

[41] Стаменковски, А. \& Јаќовски, Б. (2013). Промоција и однесување со потрошувачите. Скопје: Графички центар, 2013

[42] Стојовска, Н. (2014). Формулирање на маркетинг стратегија со фокус на потрошувачите. Магистерски труд. Штип: Економски факултет

[43] Стојковска, Л. \& Жупанска, Е. (2011). Маркетине. Скопје: Графички центар

[44] Wishna, V. (2000). Great expectations. Restaurant business, 99(1), 27-30.

[45] Zeithaml, A. V., Berry, L. L., \& Parasuraman, A. (1996). The behavioral consequences of service quality. Journal of Marketing, 60(2), 31-46. 